IRSH 62 (2017), pp. 45 I-477 doi: I0.1017/S002085901 7000347

(C) 2017 Internationaal Instituut voor Sociale Geschiedenis

\title{
Jean Grave and French Anarchism: A Relational Approach (I870s-I9I4)*
}

\author{
CONSTANCE B A T M A N \\ School of Literature and Languages, University of Surrey \\ Guildford, Surrey GU2 $7 X H, U K$ \\ E-mail: c.bantman@surrey.ac.uk
}

\begin{abstract}
This article proposes a biographical approach to the study of anarchist activism, applied to the French journalist, editor, theorist, novelist, educator, and campaigner Jean Grave, one of the most influential figures in the French and international anarchist movement between the late i 870 s and World War I. Adopting a relational approach delineating Grave's formal and informal connections, it focuses on the role of print in Grave's activism, through the three papers he edited between I 883 and I9I4, and highlights his transnational connections and links with progressive circles in France. Due to the central place of both Grave and his publications in the French anarchist movement, this biographical and relational approach provides a basis to reassess the functioning and key strategic orientations of French anarchist communism during its "heroic period" (I870s-1914), by stressing its transnational ramifications and links beyond the anarchist movement.
\end{abstract}

"Les Temps Nouveaux? It was Grave's paper, and that's all one needs to know." ${ }^{\mathrm{I}}$

\section{INTRODUCTION}

A randomly selected, four-page issue from i 895 , the first year of the weekly Les Temps Nouveaux ${ }^{2}$ (the continuation of the earlier Le Révolté and La Révolte), opens with a front-page article entitled "Patriotisme et Cosmopolitisme", leading to a survey of labour movement news in France, the Netherlands, Romania, and the United States. The brief "Petites correspondances" back-page section addresses individuals and organizations from all over France, Geneva, the Belgian towns of Iseghem and Morlanwelz, Buenos Aires, and, in the United States, New York, Colgate (Wisconsin), and Weir City (Kansas). In a late-I895 issue of the

\footnotetext{
* I would like to thank Bert Altena for his expert advice on this study.

I. Guillaume Davranche, Trop jeunes pour mourir. Ouvriers et révolutionnaires face à la guerre (1909-19I4) (Paris, 20I4). Unless otherwise stated, all translations from the French are my own. 2. Les Temps Nouveaux, I, 31, 30 November I895.
} 
associated (and undated) Supplément Littéraire, readers would have found an article by Russian sociologist Jacques Novicow, Belgian poet Emile Verhaeren's piece “The Stock Exchange”, an extract from Engels's The Origins of the Family, and a paragraph on "Harmful intelligence" by the French anthropologist, anatomist, and physiologist Léonce Manouvrier. ${ }^{3}$ For a set of publications launched "without capital and without any advance [...] only counting on the support of the intellectual public and the goodwill of those who know [them]", ${ }^{4}$ this thematic and geographical scope was extraordinary, yet fully characteristic. It resulted from, and enacted the activist project and skills of the paper's editor, Jean Grave.

Grave's contribution to French and international anarchist communism was pivotal, in terms of ideological elaboration as well as dissemination. Until World War I, he was one of the best connected and most influential figures in the international anarchist movement, through the prominence and sheer volume of his contacts, as well as his ability to extend and mobilize them in the context of a clear militant project relying on predominantly informal connections. Grave was the editor of three highly prominent anarchist periodicals, Le Révolté (1879-1885), La Révolte (I887-1894), and Les Temps Nouveaux (I 895-I922), which were read and broadcast anarchist ideas on a global scale, with a circulation ranging from I, 500 in their early days to I 8,000 copies at their peak, ${ }^{5}$ presumably with a much wider readership. In addition, The Presse de la Révolte and the Publications des Temps Nouveaux published dozens of pamphlets by Grave and others, and important books such as Grave's La Société Mourante et l'Anarchie (I 893), L'Anarchie, son but, ses moyens (I 899), and Les Aventures de Nono (I90I), a children's book. These publications are considered here within a broader analysis of Grave's print-based relational activism, which focuses primarily on the periodicals he edited and which were so closely associated with his work and vision.

Grave was born in I 854 into a working-class family in the Puy de Dôme region in Central France. A shoemaker by trade, he became one of the early champions of anarchism when it emerged as a distinct political movement in the late 1870 s, in the final years of the First International. Grave, initially drawn to the Marxist-inspired ideas of Jules Guesde, first started attending political meetings in Paris, before moving to Geneva at the end of 1883 to take over the editorship of Le Révolté at the invitation

3. Les Temps Nouveaux, Supplément Littéraire, 34, I895.

4. Les Temps Nouveaux, I, I, 4 May I 895.

5. Jean Grave, Le Mouvement Libertaire sous la IIIe République (Paris, 1930), pp. I 52-1 53 ; René Bianco, "Le Révolté", I00 ans de presse anarchiste (1987), available at: http://bianco.ficedl.info/; last accessed I2 April 2016; Louis Patsouras, The Anarchism of Jean Grave (Montreal, 2003), p. 37 . 
of the anarchist communist theorists Peter Kropotkin and Elisée Reclus. ${ }^{6}$ Le Révolté was subsequently relocated to Paris, and was renamed La Révolte in I 886 . By the early I 890 s, when the ideology of propaganda by the deed swept over France and beyond, Grave, primarily through his publications, had become instrumental in the elaboration and transmission of anarchist communism. He was an important voice in the transnational anarchist debate over the use of political violence and the promotion of trade unionism and the general strike within an anarchist framework. Grave retained this prominent role as the threat of a war loomed ever closer, first as a champion of antimilitarism and pacifism and, in a dramatic ideological U-turn, as a signatory to the interventionist Manifesto of the Sixteen issued in 1916. After the war, his near-complete isolation and loss of influence were both a consequence and a reflection of the demise of the movement as he saw it, because of its internal divisions (including the organizational and ideological collapse of some of its key networks) and the competition from Bolshevism. ${ }^{7}$

Except for a well-researched and insightful brief biography of Grave by Louis Patsouras, ${ }^{8}$ little in-depth attention has been paid to this central figure. Existing works focus, understandably, on Grave's ideas and writings, leaving his wide network of connections largely unexamined. This contribution addresses this gap: it argues that in order to be fully assessed, Grave's role must be examined through a relational perspective highlighting his participation in many different groups, circles, and networks active on multiple geographical scales ranging from the very local to the global, and underlining his skills in mobilizing these contacts as part of a clearlydefined militant vision and strategy. On a more personal level, this approach brings a corrective to customary portrayals of Grave as "cripplingly shy" but unabashedly doctrinaire, "primitive and uncouth", ${ }^{10}$ afflicted with a stutter which "forced him to conduct his revolutionary activity exclusively through writing or with comrades in informal egalitarian settings, formally organized groups being too stressful and painful". ${ }^{\text {II }}$ Examining Grave's liaising work and the ambitious vision underpinning it underlines his determination, versatility, and achievements as an activist and an organizer; it restores his voice and agency, and sheds light on the deep interlocking of the political and private spheres in his activism.

6. Grave, Le Mouvement Libertaire, pp. 39-46.

7. Constance Bantman and David Berry, "The French Anarchist Movement and the First World War", in Ruth Kinna and Matthew Adams (eds), Anarchism 1914-I8: Internationalism, AntiMilitarism and War (Manchester, 2017), pp. I55-174; David Berry, A History of the French Anarchist Movement, 1917-1945 (Oakland, CA, 2009).

8. Patsouras, The Anarchism of Jean Grave; Jean Thioulouse, "Jean Grave (I854-1939), journaliste et écrivain anarchiste" (PhD, Paris 7 University, I994).

9. http://anarlivres.free.fr/pages/biographies/bio_Grave.html; last accessed 9 May 2017.

I0. Les Hommes du Jour, 24 (1908), "Jean Grave”.

I I. Patsouras, The Anarchism of Jean Grave, p. 7. 
It contradicts contemporary claims that "like happy people, Jean Grave has no history", while largely confirming that "his story is that of his books, pamphlets, and papers". ${ }^{2}$

Print was indeed the prime medium for Grave's network-based activism, making him an exception, as a sedentary yet highly connected anarchist transnationalist who travelled very little at a time of intense anarchist mobility, while reaching audiences on a global scale. This makes him uncharacteristic with respect to the description of typical early twentiethcentury transnational anarchist mediators provided by the historian Kirwin Shaffer. Shaffer deploys the notion of "itinerant" activists, who "helped to solidify transnational anarchist networks [...] to galvanize fund-raising campaigns, bring a certain international 'legitimacy' to their local and national efforts, and resurrected old friendships from previous militant campaigns in other countries". ${ }^{13}$ While Grave matches all the functional attributes of such militants, one crucial aspect is missing: mobility. This is indeed a key, often implicit feature for transnational activists, in a movement where forced and voluntary mobility was so prevalent, and Grave's sedentary activism contrasts with many of his contemporaries - a reminder that ideological dissemination does not necessarily require personal mobility, just connectors and intermediaries, as stressed by Pierre-Yves Saunier. ${ }^{14}$ Grave's specificity is that his connecting activities were largely mediated by his publications, which, through their extensive circulation, counteracted his own sedentariness. In addition, the fact that Grave did not speak any language other than French was counteracted by his close links with a vast network of international anarchists and occasional translators, who supported the international make-up and diffusion of his publications. Emphasizing the role of print-based activism also explains partly the paradoxical historiographic treatment which Grave has received, as a militant who is mostly discussed within a strictly French context, whereas many studies on global anarchism mention the presence and impact of his successive publications far beyond France, making Les Temps Nouveaux "one of anarchism's most important and popular journals". ${ }^{\text {Is }}$

I 2. Les Hommes du Jour, "Jean Grave".

I3. Kirwin Shaffer, Black Flag Boricuas: Anarchism, Antiauthoritarianism, and the Left in Puerto Rico, I897-I92 I (Urbana, OH, 2013), p. I I.

I4. Pierre-Yves Saunier, Transnational History (Basingstoke, 201 3), pp. 33-57.

15. Iain McKay, "Kropotkin, Woodcock and Les Temps Nouveaux", Anarchist Studies, 23:1 (2015), p. 7. See for instance STIOBHARD, "Armenia", 27 April 2015, available at: http://raforum.info/spip.php?article32 I9; last accessed I June 2016. Bert Altena notes that "Grave brought anarchism from the whole world to the table of the individual reader [...]. Grave's journals are indispensable for reconstructing the history of Dutch anarchism during the 1830 ". Bert Altena, "Anarchism as a Social Movement, 1870-1940", Sozial.Geschichte Online, I 8 (2016), pp. I $5-62,50$. 
Examining Grave's print networks explains away this apparent contradiction.

The study of his print activism casts a new light on Grave; given his central role in the movement, it also brings new insights into the broader French anarchist communist tradition. It emphasizes Grave's significance in connecting French anarchist circles with a wider artistic and literary intelligentsia and a politically progressive front - two sets of connections that have not been examined together and systematically. In terms of methodology, it integrates ongoing research into personal and political networks with the substantial historiography exploring the cultural politics of anarchism, and examines the latter from a political perspective. Grave's example illustrates the key role of these collaborations as a reputational asset for the movement: they account for its resilience in critical times - for instance the anti-anarchist "Trial of the Thirty" (I894) in which Grave was indicted - as well as its lasting (counter)cultural influence.

Secondly, this relational perspective shows the full extent of Grave's internationalization - a dimension often overlooked or downplayed in works on both Grave and the wider French anarchist movement. ${ }^{16}$ Patsouras's excellent biography predates the "transnational turn", which has opened new historiographic perspectives for the anarchist movement and is fully relevant to understand Grave's life and militancy. Similarly, Jean Maitron's Histoire du mouvement anarchiste en France (1975), a landmark study on French anarchism that remains fully up to date in all other respects, has an overwhelmingly national focus, as do more recent works, even when exploring new methodologies and themes, such as the role of networks in the movement or terrorism, antimilitarism, and pacifism. This contribution supplements the historiography of French anarchism by stressing the integral importance of international links and ideological inputs to the conception and diffusion of anarchist communism in France at certain times, with Grave and his publications acting as key intermediaries in these multidirectional transfers. In this instance, the biographical angle provides a new understanding of the nature and functioning of the wider movement. This approach converges with the growing body of studies on transnational anarchism, although it adopts a relatively new angle by examining a largely "immobile transnationalist" operating through print journalism, rather than personal mobility as a vector for transnational militancy and ideological exchange. In the context of French anarchism (as in many other national historiographies), the study of exiled and

16. Jean Maitron, Histoire du mouvement anarchiste en France (I880-19I4) (Paris, I955); Vivien Bouhey, Les Anarchistes contre la République. Contribution à l'bistoire des réseaux sous la Troisième République (I880-1914) (Rennes, 2008); Richard D. Sonn, Anarchism E Cultural Politics in Fin de Siècle France (Lincoln, 1989); Davranche, Trop jeunes. 
immigrant groups has been the primary lens to stress the movement's international dimensions, whether it be the international activism of individual militants, ${ }^{17}$ immigrant groupings in France $^{18}$ (a line of inquiry that remains incomplete, notably with respect to Italian and Spanish anarchists before I9I4), or by studying groups of French-speaking anarchists who left the country. ${ }^{19}$ Grave's print-based activism illustrates a related yet different and very effective form of transnationalism. Moreover, it challenges nationally focused and diffusionist accounts, by portraying the French movement as an active participant in international tactical debates and undertakings, and a recipient rather than simply a source of ideological influences: it shows the ideological and organizational centrality of internationalism to French anarchist communism and propaganda, as well as the transnational construction of key anarchist communist ideas promoted by Le Révolté and its successors, in particular through the links with Peter Kropotkin.

This survey provides a more comprehensive and systematic assessment of Grave's activism, and of the history of French anarchist communism and its functioning as a social movement. Grave's papers were remarkably long-lived, produced and disseminated by small but complex, very productive, and resilient transnational networks. These were also occasionally connected with non-anarchist circles, groups, and organizations, resulting in added impact and a profound influence in shaping the French anarchist communist tradition. For a movement faced with linguistic heterogeneity, repression, a chronic lack of funds, and considerable internal dissent, in which periodicals appeared and disappeared quickly, this shows great resourcefulness and continuity. Once these conditions were altered, as was the case after I91 8 in France, when more formal and stable labour organizations rose in prominence, network-based activism tended to recede in importance. This later period also witnessed the collapse of Grave's own networks, resulting in his near-complete marginalization.

17. Guillaume Davranche et al. (eds), Les Anarchistes. Dictionnaire biographique du mouvement libertaire francophone (Paris, 20I4); John Merriman, The Dynamite Club: How a Bombing in Fin-de-Siècle Paris Ignited the Age of Modern Terror (Boston, MA and New York, 2009).

I8. René Bianco, "Le mouvement anarchiste à Marseille et dans les Bouches du Rhône (I880I9I4)" (PhD, Université de Provence, I977); Jean-Marc Izrine, Les Libertaires du Yiddishland (Paris, 20I4); Gaël Cheptou, "Le Club de lecture des sociaux-démocrates allemands de Paris: de l'exil à l'immigration (I877-1914)", Matériaux pour l'bistoire de notre temps, 4:84 (2006), pp. I $8-25$.

19. Constance Bantman, The French Anarchists in London: Exile and Transnationalism in the First Globalisation (Liverpool, 2013); René Bianco, Ronald Creagh, and Nicole Riffaut-Perrot, Quand le coq rouge chantera. Bibliographie. Anarchistes français et italiens aux Etats-Unis d'Amérique (Montpellier, 1986); Michel Cordillot, Révolutionnaires du Nouveau Monde. Une brève histoire du mouvement socialiste francophone aux Etats-Unis (I885-I 922) (Montreal, 2010). 


\section{Les Hommes du jour}

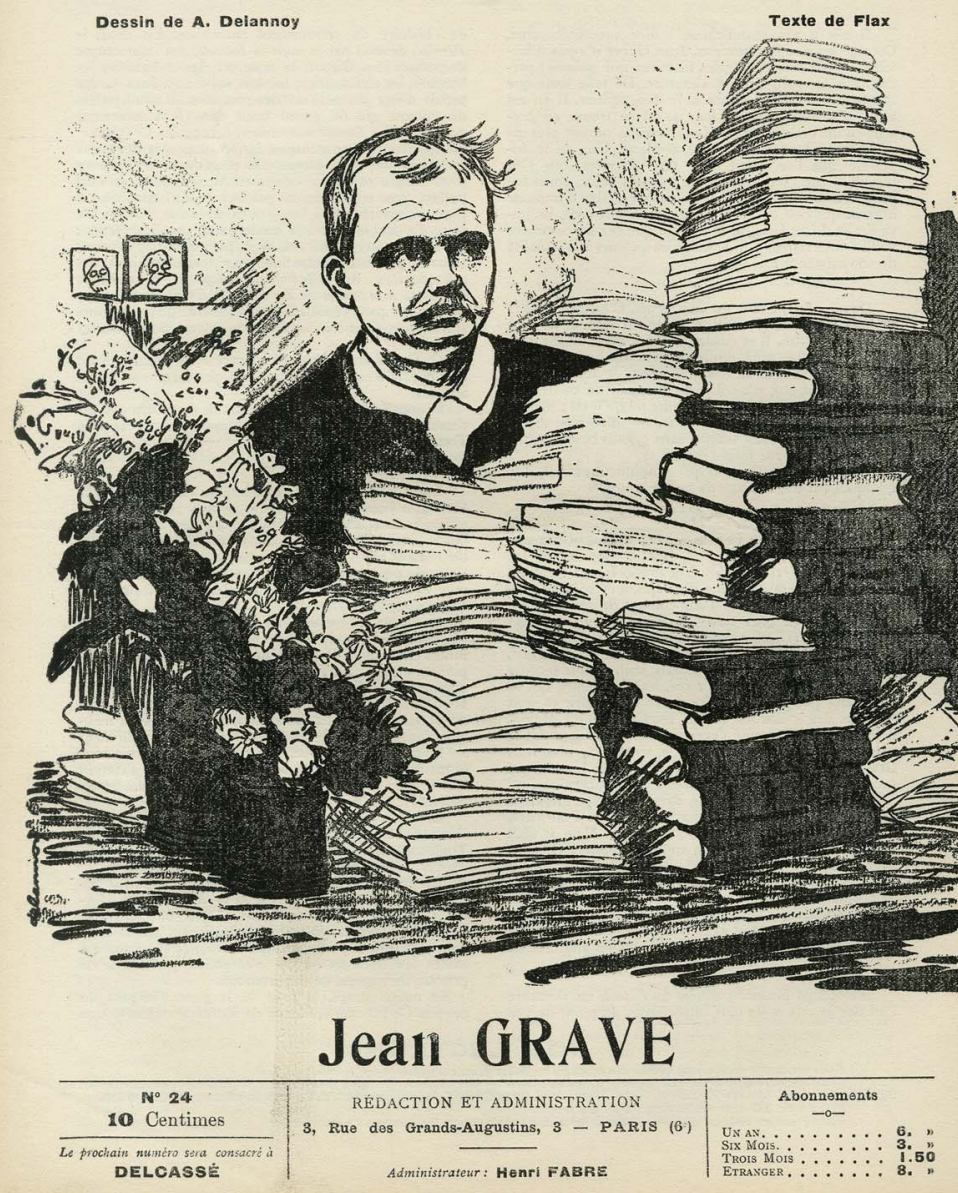

Figure I. Jean Grave. Drawing by A. Delannoy on the cover of Les Hommes du jour, no. 24 (1908).

Source: Library of the International Institute of Social History, Amsterdam, The Netherlands.

\section{DEFINING A RELATIONAL APPROACH}

The notion of "relational" activism is rooted in social movement theory. Applying it to the study of veganism as a cultural movement, Cherry defines a "relational approach" very precisely, in opposition to "substantialist" 
approaches "consider[ing] social actors as pre-formed entities who act rationally in specific situations. Relational thought, in contrast, describes aspects and phases of action, without attributing action to outside entities" ${ }^{2 \circ}$ The definition used here is more general, and focuses on the identification and depiction of militant connections rather than the transformational processes they induce. It is aligned with the definition formulated by Sara O'Shaughnessy and Emily Huddart Kennedy: "We introduce the term 'relational activism' to call attention to the way that relationship-building work contributes to conventional activism and constitutes activism in and of itself". ${ }^{2 \mathrm{I}}$ This concept is especially useful to rectify the prevailing, romantic depiction of Grave as a theorist, an intellectual championing a brand of anarchism which "expounded anarchist ideas, but failed to exemplify them", ${ }^{22}$ overlooking his proactive organizing work. It also points to the predominantly informal nature of these links, which were juxtaposed with more stable and formal types of cooperation.

While such a study has never been carried out regarding Grave specifically, examining informal links has emerged as an important trend in anarchist historiography in the last decade, resulting in a great wealth of empirical studies on anarchist transnationalism, emphasizing informal links mediated by individuals, small groups, and their publications. Davide Turcato's landmark article "Italian anarchism as a transnational movement, I88 5-I9I 5" (2007) was one of the earliest exposés of the merits of the transnational angle to study anarchist movements, notably in highlighting a level of militant continuity and coherence in times of crisis that methodological nationalism fails to capture, because of the transnational functioning of Italian anarchism. ${ }^{23}$ In sync with and in the wake of this study, there has been great progress towards mapping out local, national, regional, and global anarchist movements and their network-based activism. This collective endeavour has shown the near-global presence of anarchist activism; recent studies have examined, for instance, JapaneseRussian connections, ${ }^{24}$ transnationalism in and around New Zealand, ${ }^{25}$ as well as diverse colonial and postcolonial contexts. ${ }^{26} \mathrm{~A}$ major point is the great

20. Elizabeth Cherry, "Veganism as a Cultural Movement: A Relational Approach", Social Movement Studies, 5:2 (2006), pp. I55-170, I 57.

2г. Sara O'Shaughnessy and Emily Huddart Kennedy, "Relational Activism: Reimagining Women's Environmental Work as Cultural Change", Canadian Journal of Sociology/Cabiers canadiens de sociologie, 35:4 (2010), pp. 551-572.

22. Sonn, Anarchism \& Cultural Politics, p. 56.

23. Davide Turcato, "Italian Anarchism as a Transnational Movement, I 88 5-191 5", International Review of Social History, 52:3 (2007), pp. 407-444.

24. Sho Konishi, Anarchist Modernity: Cooperatism and Japanese-Russian Intellectual Relations in Modern Japan (Cambridge, MA, 20I3).

25. Jared Davidson, Sewing Freedom: Philip Josephs, Transnationalism E Early New Zealand Anarchism (Oakland, CA, 2013).

26. Benedict Anderson, Under Three Flags: Anarchism and the Anti-Colonial Imagination (London, 2008); Steven Hirsch and Lucien van der Walt (eds), Anarchism and Syndicalism in the 
functional versatility of informal connections: ${ }^{27}$ transnational networks can be vectors to plot terrorist attacks, ${ }^{28}$ the means to organize and disseminate anarchist pedagogical ventures or antimilitarist propaganda, ${ }^{29}$ and also the arteries through which money, information, and print - the lifelines of propaganda - circulated.

Different interpretations of the nature and significance of these anarchist networks can be identified: the intensely relational, networked, and predominantly informal nature of anarchist activism impacts the conceptualization of anarchism as a social movement. Academic and even public interest in anarchist networks has been spurred by apparent similarities between anarchist and contemporary terrorist networks - especially so at times when terrorist attacks have prompted a search for historical precedents to the current wave of terrorism, as with $9 / \mathrm{I}$ I and the $7 / 7$ attacks in London. ${ }^{30}$ As Grave's example - among many others - shows, this is an extremely reductive interpretation of the movement and the role of informal connections within it. In contrast, social space theory and globalization studies have emerged as productive interpretative frameworks, for instance in the work of Tom Goyens, building on Henri Lefebvre's theories on the production of space,

Colonial and Postcolonial World, I870-1940: The Praxis of National Liberation, Internationalism, and Social Revolution (Leiden, 2010); Barry Maxwell and Raymond Craib (eds), No Gods, No Masters, No Peripheries: Global Anarchisms (Oakland, CA, 2015).

27. David Berry and Constance Bantman (eds), New Perspectives on Anarchism, Labour and Syndicalism (Newcastle upon Tyne, 2010); Pietro Di Paola, The Knights Errant of Anarchy: London and the Italian Anarchist Diaspora (1880-1917) (Liverpool, 2013); Geoffroy de Laforcade and Kirwin R. Shaffer (eds), In Defiance of Boundaries: Anarchism in Latin American History (Gainesville, FL, 2015); Constance Bantman and Bert Altena (eds), Reassessing the Transnational Turn: Scales of Analysis in Anarchist and Syndicalist Studies (London, 2015).

28. See for instance Timothy Messer-Kruse, The Haymarket Conspiracy: Transatlantic Anarchist Networks (Urbana, OH, 20I 2); Merriman, Dynamite Club.

29. See for instance the international liaison papers Bulletin de l'Internationale anarchiste (Liège, 1906-1907), Bulletin de l'Internationale libertaire (London, 1908), and Bulletin International du mouvement syndicaliste (Paris and Amsterdam, I907-1914).

30. Tom Armitage, "Commentary", New Statesman, 8 August 2005; Anon., "For Jihadist, Read Anarchist", The Economist, I 8 August 2005; Michael Collyer, "Secret Agents: Anarchists, Islamists and Responses to Politically Active Refugees in London", Ethnic and Racial Studies, 28:2 (2005), pp. 278-303; Antony Taylor, "London Bombings and Alien Panics", Chartist, November-December 2005; Michael Burleigh, Blood and Rage: A Cultural History of Terrorism (London, 2008); Ersel Aydinli, "Before Jihadists There Were Anarchists", Studies in Conflict and Terrorism, 31:10 (2008), pp. 903-923; Richard Bach Jensen, "The International Campaign against Anarchist Terrorism, I880-1930s", Terrorism and Political Violence, 2 I:I (2009), pp. 89-109; Merriman, Dynamite Club; James Gelvin, "Al-Qaeda and Anarchism: A Historian's Reply to Terrorology", Terrorism and Political Violence, 20:4 (2008), pp. 563-58 I, and the ensuing replies: Leonard Binder, "Comment on Gelvin's Essay on Al-Qaeda and Anarchism”, Terrorism and Political Violence, 20:4 (2008), pp. 582-588; Richard Bach Jensen, "Nineteenth Century Anarchist Terrorism: How Comparable to the Terrorism of al-Qaeda?", Terrorism and Political Violence, 20:4 (2008), pp. 589-596. 
examining how networks structure social space, and describing them as alternative, countercultural, and oppositional spaces. ${ }^{3 \mathrm{I}}$ Goyens's analysis of the spatial dimensions of counterculture can be transposed to both transnational networks and periodicals as important alternative spaces where anarchist identities and ideas were constructed and deployed. ${ }^{32}$ Organizational and ideological convergences between pre-I9I4 anarchism and contemporary social movements such as the global justice or alter-globalization movements have meant that social movement theories have emerged as possible paradigms to analyse anarchist transnationalism. ${ }^{33}$ As "the largest political movement organized from below" 34 in the late nineteenth century, anarchism can certainly claim a special place in the proto-history of global social movements. In this perspective, the term "network" points to similarities with specific forms and traditions of political militancy, notably the "transnational advocacy networks" examined by Margaret E. Keck and Kathryn Sikkink. ${ }^{35}$

Social movement theories also offer possible theoretical models to comprehend Grave's role as a network node and organizer. He may be seen as an example of Charles Tilly's "social movement entrepreneurs deliberately organiz[ing] across international boundaries" in order to "outflank national authorities", in a phase of internationalization of social movements. ${ }^{36} \mathrm{He}$ also offers an interesting variation on Tarrow's "rooted cosmopolitan", defined by "relational links to their own societies, to other countries, and to international institutions", activists who "face both inward and outward and combine domestic and transnational activism and advocacy", in increasingly intertwined societies. Tarrow provides additional criteria to portray these transnational activists: "They are better educated than most of their compatriots, better connected, speak more languages, and travel more often.”

3I. Tom Goyens, Beer and Revolution: The German Anarchist Movement in New York City, I880-19I4 (Ithaca, NY, 2007); idem, "Social Space and the Practice of Anarchist History", Rethinking History: The Journal of Theory and Practice, I 3:4 (2009), pp. 439-457.

32. Actor-network theory has also been mobilized by Kathy Ferguson in studies on anarchist material culture, and, in a non-anarchist context, by Frank Wolff in his studies on the Bundist movement, to examine the construction of transnational political identities in exilic contexts. Frank Wolff, "Eastern Europe Abroad: Exploring Actor-Networks in Transnational Movements and Migration History, The Case of the Bund", International Review of Social History, 57:2 (20I2), pp. 229-255; Kathy Ferguson, "Anarchist Printers and Presses: Material Circuits of Politics”, Political Theory, 42:4, (20I4), pp. 39I-4I4.

33. Carl Levy, "Anarchism and Cosmopolitanism", Journal of Political Ideologies, I6:3 (201 I), pp. $265-278$.

34. José Moya, "Anarchism", in Akira Iriye and Pierre-Yves Saunier (eds), The Palgrave Dictionary of Transnational History (New York, 2008), pp. 39-4I, 39.

35. Margaret E. Keck and Kathryn Sikkink, "Transnational Advocacy Networks in International and Regional Politics" (1999), available at: http://isites.harvard.edu/fs/docs/icb.topic446176.files/ Week_7/Keck_and_Sikkink_Transnational_Advocacy.pdf; last accessed 30 May 2016.

36. Charles Tilly and Lesley J. Wood, Social Movements I768-20I2 (Abingdon, 20I3 [3rd ed.]), p. 63 . 
They are distinguished by "their ability to shift between levels and take advantage of the expanded nodes of opportunity of a complex international society". ${ }^{37}$ Grave shows both the relevance and limitations of an earlier transposition of this broad archetype, since he fulfilled the roles of a transnational advocate and organizer within the anarchist movement without fully matching the sociological traits and patterns listed by Tarrow. This relative mismatch may derive from the widely different degrees of internationalization between contemporary globalization, as theorized by Tarrow, and the pre-I9I4 period of the "first globalization", to which Grave pertains. Moreover, since, like Grave, many anarchists were self-taught and of working-class extraction, the accumulation of the kind of social and cultural capital described by Tarrow was problematic. Indeed, Tarrow, citing Appiah, points out that "transnational activists, for the most part, are better educated than most of their compatriots, better connected, speak more languages, and travel more often". ${ }^{38}$ As discussed above, aside from being well-connected, none of these characteristics applied to Grave, although it is remarkable that they could be found in his personal networks and his publications. This confirms the relevance of Tarrow's analysis, albeit with a shift from the individual to the network.

This article uses the term "network" in a non-formal acceptation, to describe evolving associations of varying size, intensity, density, and geographical reach. It is especially effective to capture the specificities of anarchist organization and the functioning of the anarchist movement at the international level..$^{39}$ It stresses the pivotal agency of individuals and their associations and connections, their variations in shapes and complexity, and - at the looser end of the organizational spectrum - the intermittent nature of such associations. This broad, metaphorical understanding of networks ${ }^{4}$ does not preclude quantitative approaches and formal analysis. The anarchist movement has also proven very well-suited to the latter, notably with the use of prosopographical databases or indeed network mapping. ${ }^{4 \mathrm{I}}$ Andrew Hoyt has carried out whole-network analyses based on Italian sovversivi networks in the United States, mapping out weak and strong bonds between individuals, collectives, and key publications, connected by

37. Sidney Tarrow, Strangers at the Gates: Movements and States in Contentious Politics (Cambridge, 20I2), p. I 86.

38. Ibid.

39. Constance Bantman, "Internationalism Without an International? Cross-Channel Anarchist Networks, I880-1914”, Revue Belge de Philologie et d'Histoire, 84:4 (2006), pp. 96 I-98 I.

40. For a critique of such metaphorical uses, see Claire Lemercier, "Formal Network Methods in History: Why and How?", available at: halshs.archives-ouvertes.fr/halshs-0052 I 527 v2; last accessed I June 2016. Claire Lemercier, "Analyse de réseaux et histoire”, Revue d'histoire moderne et contemporaine, 52:2 (2005), pp. 88-I I 2.

4I. See Pietro Di Paola's research project “Towards a prosopographical history of Italian Anarchists” (Skills Acquisition Award SQ I 20027, British Academy, 20I3). 
arrows representing established connections, collaborations, relationships, and mentions in publications. ${ }^{42}$ One of Hoyt's key conclusions is that such maps display numerous bridges and connections within the movement, whereas purely narrative accounts tend to over-emphasize ideological sectarianism.

While the term "network" does not, of course, appear in the substantial literature on organization generated by nineteenth-century anarchists, it is very commonly used by historians of anarchism, ${ }^{43}$ notably to depict what George Woodcock has termed "the loose and flexible affinity group" so fundamental to pre-19I4 anarchist organization. ${ }^{44}$ It also matches the way in which many communist anarchists, including Grave, conceived of optimal organization in the period before World War I. Tactical organization was a central concern for Grave; he saw groups and individuals as the building blocks of anarchism, and pressed for modes of communication and exchange which are evocative of networks insofar as connections were perceived as an essential requirement which, however, did not require constant and established links. Thus, when he advocated "direct relations between groups, even when we do not share exactly the same views on all points. [...] It is necessary to know one another, to exchange ideas, to lend mutual support to the best of our forces". ${ }^{45} \mathrm{He}$ aimed for "a strong core of groups and individuals keeping systematic relations. [...] It would be urgent to establish the greatest possible number of relations between groups and individuals, as long as these relations are spontaneous, direct, and unmediated". ${ }^{46}$ This is the strategic vision he enacted through his periodicals, using the latter as a medium for these relations.

Despite the importance of informal links, their coexistence with more institutional or binding connections must be emphasized, as well as the close imbrication of the personal and the political. Le Révolté and Grave's other publications were produced through core collaborations which were stable over time and implied regular (i.e. weekly or monthly, if not daily) contact over several years, for instance with Lucien Guérineau,

42. Andrew Hoyt, "Methods for Tracing Radical Networks: Mapping the Print Culture and Propagandists of the Sovversivi", in Jorell A. Meléndez Badillo and Nathan J. Jun (eds), Without Borders or Limits: An Interdisciplinary Approach to Anarchist Studies (Newcastle, 2013), pp. 75 -106.

43. See, among others, Davide Turcato, Making Sense of Anarchism: Errico Malatesta's Experiments with Revolution (Basingstoke, 2012); Di Paola, The Knights Errant of Anarchy; Matthew Adams, "Memory, History, and Homesteading: George Woodcock, Herbert Read and Intellectual Networks”, Anarchist Studies, 23:I (201 5), pp. 86-I04; Kirk Shaffer, “Tropical Libertarians”, in Hirsch and Van der Walt, Anarchism and Syndicalism in the Colonial and Postcolonial World, pp. 273-320. Federico Ferretti, Elisée Reclus. Pour une géographie nouvelle (Paris, 2014).

44. George Woodcock, Anarchism (Harmondsworth, I970 [2nd ed.]), p. 256.

45. Jean Grave, Organisation, Initiative, Cohésion (Paris, 1902), pp. 17-20.

46. Ibid., pp. 2 I-29. 
Paul Delesalle, André Girard, and Dr Pierrot. These individuals formed the "Groupe des Temps Nouveaux". The use of the term "group" points to very close collaborations, for which terms connoting formal links (for instance group, circle, union, "syndicat") were deemed more appropriate by the actors themselves. To some extent, this hybrid organization can be extrapolated to the anarchist communist movement, where "loose and flexible" associations were juxtaposed with attempts at formal organization, such as short-lived Internationals, groups coalescing around projected congresses or campaigns, and, at the national level, long-lasting groups and federations.

Grave commanded one of the largest and most durable sets of connections, and was a key intermediary and organizer in pre-war international anarchism. The main sources to identify his contacts are his periodicals and related publications, his memoirs, his correspondence (held at the Institut Français d'Histoire Sociale (IFHS), now hosted by the Archives Nationales in Pierrefitte, and as part of various correspondents' archives at the International Institute of Social History (IISH) in Amsterdam), as well as police sources held in France. However, much remains undocumented, especially since many sources were seized by the police or pre-emptively destroyed by the anarchists themselves. As Grave wrote to Max Nettlau about one of the most eventful years of the heroic period: "There is no letter left from I 893 , the times were too complicated and they were all burnt." 47

The outline of Grave's relations below is thematic, aiming to locate key networks and underline the transnational dimensions of his activism, as well as his connections within artistic and intellectual circles. The chronology of the different stages of Grave's militant evolution, their links with the broader French and international movements, and his networks is aligned with the traditional periodization adopted in most studies on French anarchist communism, namely late i 870 s to early i 880 os: early days and development of the anarchist movement; early I 890 : era of propaganda by the deed, marked by organizational disruption and ideological division; mid-I 895-I9I4: organization and ideological reorientation and fragmentation, syndicalist, and antimilitarist propaganda in the run up to the World War I; and post-World War I: ideological reconfiguration and generational change.

\section{KEY INTERNATIONAL CONNECTIONS}

"If you need a heart to find sympathy - not the kind that can be replaced but, at least, the one friendship can give - be assured that you already have it. If I was free, I would tell you: come, let's take a walk, and talk, together - all I can do now is embrace you strongly, very strongly,

47. Letter dated 8 October 1930, Correspondence with Grave, Max Nettlau Papers, inv. no. 505, International Institute of Social History, Amsterdam (hereafter, IISH); it is not clear what happened to Grave's letters to Kropotkin. 
in thought." ${ }^{38}$ Thus begins the first letter from Kropotkin to Grave held at the IFHS, written in I 885 , after the death of Grave's first wife. It provides a remarkable insight into what, by then, was already a strong friendship (despite the use of the vous form in the French original until I90I), interwoven with a long and thriving militant and intellectual partnership, on an equal footing despite Kropotkin's towering status in the movement. This collaboration underpinned the production of the papers, from the creation of Le Révolté to World War I. While the papers were closely associated with Paris and the rue Mouffetard where the Temps Nouveaux office was located and Grave lived for many years, ${ }^{49}$ their elaboration was transnational, originating in a core set of connections within the milieu of the First International and the Jura Federation. Le Révolté was set up in I 879 in Geneva by Peter Kropotkin, Elisée Reclus, François Dumartheray, and George Herzig, who then asked Grave to take over, ${ }^{50}$ his name having been suggested by Kropotkin's wife Sophie. Grave accepted "straightaway", even though he had no editorial or typesetting experience at that point. ${ }^{5 \mathrm{I}}$ Other leading anarchist communist thinkers and activists - Warlaam Tcherkesoff, Saverio Merlino, Errico Malatesta, Christian Cornelissen, and James Guillaume - contributed frequently and were in regular contact with Grave. New links were then formed, with other figures personally or ideologically connected with the First International (for example, Max Nettlau, Paul Reclus, Jacques Gross). ${ }^{52}$ Grave himself and his papers were ideological and organizational nodes of this influential and durable transnational network, which overlapped with other networks, for instance the geographers' networks centring on Elisée Reclus and Peter Kropotkin. ${ }^{53}$

Of central importance was the editorial partnership with Kropotkin, who was in exile in London from the mid-I880s until the early I90os, subsequently moving to the south coast of Britain and Italy. In London, between I 886 and the early i 890 s, Kropotkin oversaw the publication of Freedom, the "brother-in-arms" 54 of Grave's own periodicals. Their archived correspondence represents only a fraction of the actual exchanges, with about fifty letters between I885 and i920. These letters testify to a close and

48. Letter from Kropotkin, 7 November 1885 , Grave correspondence, Institut Français d'Histoire Sociale, Paris (hereafter, IFHS).

49. Alexander Varias, Paris and the Anarchists: Aesthetes and Subversives during the Fin de Siècle (Basingstoke, 1996).

50. "Comment fut fondé Le Révolté", Les Temps Nouveaux, 20 February 1904; 27 February 1904; 5 March 1904.

5I. Grave, Le Mouvement Libertaire, p. 39.

52. Correspondence with Jean Grave, Jacques Gross Papers, inv. no. 47, IISH, c. 188 5-1 888, I 893 , I 895-1897, [1900], 1901-1903, [1905], I91 5-[1916?], and n.d.

53. Federico Ferretti, "Anarchism, Geography and Cosmopolitanism in the Age of Empire", Paper presented at the ESSHC, Valencia, 30 March-2 April 2016.

54. Freedom, November I 888 . 
multifaceted militant and personal relationship, whereby both men exchanged information, opinions, contacts, and texts to be printed in their respective papers. The periodical press was a major outlet for Kropotkin, who published I 52 articles in Les Temps Nouveaux between I 895 and I9I 3 . As recently argued by Iain McKay, these represent an important source to chart the evolution of his political thought alongside his essay and pamphlet output, in particular with respect to revolutionary ideas and anarchist engagement with the organized labour movement. ${ }^{55}$ For the years I 895-I9I4 only, McKay has inventoried thirteen translated articles by Kropotkin, which appeared in both Freedom and Les Temps Nouveaux. Kropotkin continued to provide editorial advice to the Freedom group after his formal retirement in the late 1880 s, championing links between both publications and translations from the French papers reprinted in their British counterpart. ${ }^{56}$ Editorial matters were at the centre of many exchanges, often involving publishing networks which extended beyond the Temps Nouveaux - Freedom connection: "Here is a manuscript. I wrote it for the anniversary issue of Tierra y Libertad of 26 July (which appeared late!). When he returned the original to me, Tarrida told me I should publish it in Les Temps Nouveaux." 57

Kropotkin kept Grave abreast of British and international political developments, and advised him on punctual and general strategic matters, often seeking his views too: "I have written a preface for Pouget and Pataud's book [Syndicalism and the Co-operative Commonwealth]. I have been told this amounts to supporting the bureaucratic trend within trade unions. Is there some truth to this?" 8 Their partnership was central to the theoretical elaboration and promotion of syndicalism from the late i $880 \mathrm{os}$ onwards ${ }^{59}$ and, a few years later, through Freedom, played a major part in the international campaign against Spanish atrocities. Grave and Kropotkin relied on each other to introduce, be introduced to, or vet new contacts, within or outside anarchist circles. ${ }^{60}$ These are instances of network

55. McKay, "Kropotkin, Woodcock and Les Temps Nouveaux".

56. Letters from Kropotkin to Alfred Marsh, 26 April I 895; 22 February 1905; 20 July 1905, Alfred Marsh Papers, inv. nos I6, I06, I I 2, IISH.

57. Letter from Kropotkin to Grave, i 8 June I910, Grave correspondence, IFHS. See also, for instance, Letter from Kropotkin to Grave, I 2 January I 9 Io (about an article by Kropotkin in the French anarchist periodical Le Libertaire), Grave correspondence, IFHS.

58. Letter from Kropotkin, I 4 December I9I0, Grave correspondence, IFHS. See also letter from Kropotkin to Grave (n.d., I 893) about demonstrations in London for the eight-hour day, Grave correspondence, IFHS, letters dated 3 July 1902 (general discussion of syndicalism and European socialism); 20 August I9I I (about mass demonstrations in Britain).

59. See Kropotkin's landmark article “Ce que c'est qu'une grève”, about the London Dock Strike as an exemplar of mutual aid, in La Révolte, 7 September I 889.

60. Letter from Kropotkin to Grave, 8 February 1908, soliciting an introduction to the writer Anatole France and the human-rights organization Ligue des Droits de l'Homme in order to 
multiplier effects, a system of introductions serving propaganda in many different ways, ranging from ideological elaboration and diffusion to mutual material help and self-protection against spy infiltration.

Within this large transnational anarchist communist network, Grave's long collaboration with Max Nettlau also stands out. Nettlau, like Grave, engaged in much network-building and network-recording activity, ${ }^{6 \mathrm{I}}$ as attested of course by the remarkable collection he sold to the IISH. From the r 880 s onwards, he often contributed to Grave's papers, reported on international movements in "Foreign notes", and established connections with international groups or individuals, who then sent correspondence about their movement or subscribed to Grave's papers. After i 895, Nettlau oversaw Freedom's "Foreign notes"; ${ }^{62}$ Grave and he exchanged large quantities of international anarchist literature across the Channel, which were sold on to readers. Nettlau helped Grave set up new international links: "Try to give me the exact address of the Norwegian paper - and that of the Czech paper." ${ }^{3}$ And, of course, both men also coordinated fundraising campaigns, as with the I9I 2 "P.K." subscription, which, Nettlau noted, had been very successful in Britain, Switzerland, and the Netherlands. ${ }^{64}$

Noteworthy are similar albeit less intensive relations with other mediators in international anarchist movements, notably collectors and antiquarians as well as militants, like the German Paul Eltzbacher and the Swiss Jacques Gross. Grave's correspondence with Gross evidences sustained mutual assistance in reaching third parties, to secure information, money, and print or disseminate militant literature, ${ }^{65}$ showing the multiple functions a personal connection could serve. In all these instances the tone of the exchanges also points to the intersection of the personal (friendship) and militant spheres, in line with the observation that "relational activism intentionally uses the private sphere in a public way, contributing to mid- and longterm change" ${ }^{66}$ These exchanges involved the best-known

enlist their support to protest against mass expulsions of Russian exiles from France. Jean-Marc Delaunay, "La Ligue de défense des droits de l'homme et du citoyen et les affaires espagnoles au début du XXe siècle", Relations internationales, I3 I (2007), pp. 27-38.

6r. See Bert Altena, "A Networking Historian: The Transnational, the National, and the Patriotic in and around Max Nettlau's Geschichte der Anarchie", in Bantman and Altena, Reassessing the Transnational Turn, pp. 62-79.

62. Letter from Alfred Marsh, is November, i 895, Nettlau Collection, inv. no. 804, IISH.

63. Correspondence with Jean Grave, 8 October I 889, Nettlau Collection, inv. no. 504, IISH.

64. Letter from Nettlau to Grave, 22 November 1912, Grave correspondence, IFHS.

65. See for instance Correspondence with Jean Grave, letter dated I 3 January I 902, Jacques Gross Papers, inv. no. 47, IISH: Grave asks Gross to go and see one Jolkovsky, in Geneva, the owner of a Russian press entrusted by Grave with the printing of the Russian translation of his book La Société mourante for I,000 francs, but who had vanished and seems about to swindle Grave. 66. O’Shaughnessy and Huddart Kennedy, "Relational Activism”, p. 5. 
militants of the time as well as unknown individuals, making them fascinating testimonies about the social history and functioning of the anarchist milieu.

Grave's international network also comprises the myriad of correspondents and contacts who read the paper and fed into it more or less regularly, and who were "weak ties" with a key role in the diffusion of the papers. They included "J.G. in Madrid", ${ }^{67}$ Edward Greene in Armenia, "F." in Nouméa, ${ }^{68}$ and "N.V. in Sao Paulo", who arranged for copies of Les Temps Nouveaux to be sent to "J.P., Montevideo". ${ }^{69}$ Even an unsystematic survey highlights the periodicals' wide reach, in terms of both dissemination and thematic coverage; the map of anarchist activism thus uncovered extends far beyond French borders, across Western and Central Europe, often straddling continents. At the peak of the publications, dozens of messages would be exchanged through every issue - not individually significant, but pieced together, over time, showing the paper's key organizing role as a "node" or a "hub" for the movement.

\section{RELATIONS AND REPUTATION: GRAVE'S CONNECTIONS WITH ARTISTS AND INTELLECTUALS}

The papers' artistic and literary contributors and supporters form another network, which served different purposes and had transnational ramifications too. Artistic and literary contributors provided an essential lifeline in reputational and financial terms, and gave the movement a decided cultural emphasis, making it a profound and long-lasting countercultural influence.

Les Temps Nouveaux was the most consistent and long-lasting French publication in fostering an anarchist artistic and literary canon. It articulated a political message for and through artistic content, by printing literature and works of visual art alongside straightforward political contents. Grave himself has been described as "the leading figure in socialism to use art to propagate its ideals in the pre-World War I period"..$^{70}$ By I 895 , when Les Temps Nouveaux was launched, the connection between avant-garde artists and anarchism was well-established: without going as far back as Courbet and Proudhon's association, it was showcased in contemporary anarchist papers such as Emile Pouget's Père Peinard and a number of avantgarde literary reviews publishing writers with anarchist leanings. ${ }^{71}$

67. Les Temps Nouveaux, 9 December 1899, p. 4.

68. Ibid., 9 July i904, p. 6 and p. 8 respectively.

69. Ibid., 2 I August 1909, p. I 2.

70. Patsouras, The Anarchism of Jean Grave, p. 94.

7I. Pierre Lachasse, "Revues littéraires d'avant-garde", in J. Pluet-Despatin, M. Leymarie, and J.-Y. Mollier (eds), La Belle Époque des revues I880-1914 (Caen, 2002), pp. I I9-I43, I24; Caroline Granier, Les briseurs de formules. Les écrivains anarchistes en France à la fin du XIX ${ }^{e}$ 
Symbolist reviews were especially receptive to libertarian ideas, due to their shared intellectual and anti-establishment individualism, albeit with different emphases; Les Entretiens politiques et littéraires and La Revue blanche had a more social and political tone than Le Mercure de France and La Plume, for instance. Over the years, the anarchist press published texts and illustrations from a diverse group of contributors. Some had durable anarchist leanings or convictions, such as the writers Octave Mirbeau and Bernard Lazare, and visual artists Lucien Pissarro, Maximilien Luce, Paul Signac, Théo Van Rysselberghe, and Théophile Steinlen. Others had passing affinities or just a sense of solidarity, ranging from the novelist and essayist Emile Zola to the far-right polemicist and novelist Maurice Barrès. These artistic connections sometimes extended transnationally. The British artist Walter Crane drew the frontispiece of Les Temps Nouveaux, while the French painter Pissarro contributed etchings to the London-based anarchist periodical The Torch, which promoted similar conceptions about art and politics. Remarkably, the Temps Nouveaux's literary and artistic contents were reinvigorated after I 894, at a time when many artists turned their backs on anarchism in the wake of the terrorist period, showing anarchism to have been something of a fad in high society and avant-garde circles. ${ }^{72}$ Overall, the paper received contributions from as many as sixty artists, including the near majority of the Neo-Impressionist movement. ${ }^{73}$

The Supplément Littéraire de La Révolte (1888-i 894) and Supplément Littéraire des Temps Nouveaux (1895-1914), published with the paper every Saturday, were a key site for international literary anarchism. ${ }^{74}$ The first issue of the Temps Nouveaux's Supplément set an eclectic libertarian tone, characterized by a strong dose of ideological ecumenism, a great diversity of genres, and a somewhat didactic, not quite avant-gardist approach..$^{75}$ It featured extracts by Herbert Spencer (on man's adaptation to a society without government), William Thackeray ("Moral Compression"), Jonathan Swift ("The Art of Political Lying”), symbolist poet Adolphe Retté, the parliamentary politician and erstwhile anarchist Georges Clemenceau (“The Social free-for-all”), alongside those of

siècle (Cœuvres-et-Valsery, 2008); Joan Ungersma Halperin, Félix Fénéon: Aesthete and Anarchist in Fin-de-Siècle Paris (Yale, CT, I988); Gaetano Manfredonia, "L'Individualisme anarchiste en France, I880-1914" (Advanced Dissertation, IEP de Paris, 1984).

72. See Emile Zola's parody of mondain anarchism in his novel Paris (1897); Ernest Carassus, Le Snobisme et les lettres françaises (Paris, I966), pp. 370-382.

73. Aline Dardel, “Les illustrateurs des Temps Nouveaux" (2006), available at: http://adiamos-89. wifeo.com/documents/LArt-social-la-Belle-Epoque-LesIllustrateursDesTempsNouveaux-PDF. pdf; last accessed 30 May 2016.

74. René Bianco, available at: http://bianco.ficedl.info/article2025.html; last accessed 3 June 2016; Aline Dardel, Les Temps Nouveaux, I895-1914 (Paris, 1987).

75. This last point is emphasized by Sonn, who contrasts La Révolte with the more radical and bohemian Père Peinard and L'Endehors. Sonn, Anarchism E Cultural Politics, pp. I 5-16. 
lesser-known and anonymous figures. ${ }^{76}$ Subsequent issues followed the same line, with extracts by Proudhon, Elie Reclus, Joseph Addison, Huysmans, Ernest Renan - among many others.

This fusion of art, literature and politics, and ideological border-crossing have received considerable attention from literary scholars and art historians, but largely from the perspective of the artists drawn to anarchist ideas, and without a close examination of the importance and functioning of these collaborations for the anarchist movement. ${ }^{77}$ And yet, this was a two-way propagandist and creative exchange, based on the theory of L'Art Social regarding the relationship between aesthetics, society and politics, and similar social, anti-militarist, and anti-colonialist positions. These collaborations provided another essential set of support networks for Grave's propaganda. All these aspects are documented in his correspondence with the anarchist writer Bernard Lazare: they exchanged information, ${ }^{78}$ contacts, ${ }^{79}$ as well as publication material. ${ }^{80}$ Artists lent Grave and "the cause" vital financial support, directly and indirectly, by donating material to be auctioned off. As Grave later reminisced, "We could rely on the goodwill of some individuals whose reputation was established: Steinlen, Willette, Roubille, Iribe, Grandjouan, Luce, Signac, Agar, Couturier, Angrand, Delaw, Delannoy, Van Dongen, Lebasque, Jossot, Kupka." ${ }^{\text {I }}$ Still in 1900, Camille Pissarro contributed fifty francs to the paper's campaigns in support of Spanish refugees, ${ }^{82}$ and as late as I920 his grandson Ludovic offered to send Grave two hundred francs. ${ }^{83}$

76. Supplément Littéraire des Temps Nouveaux, I: I (1895).

77. Annemarie Springer, "Terrorism and Anarchy: Late igth-Century Images of a Political Phenomenon in France", Art Journal, $38: 4$ (1979), pp. 26 I-266; Robyn S. Roslak, "The Politics of Aesthetic Harmony: Neo-Impressionism, Science, and Anarchism", The Art Bulletin, 73:3 (1991), pp. 381-390; Patricia Leighten, Re-Ordering the Universe: Picasso and Anarchism, I897-19I4 (Princeton, NJ, I989); Sonn, Anarchism \& Cultural Politics; Tania Woloshyn, "Colonizing the Côte d'Azur: Neo-Impressionism, Anarcho-Communism and the Tropical Terre Libre of the Maures, c.I 892-1908", RIHA Journal, July (2012); Katherine Brion, "Paul Signac's Decorative Propaganda of the I89os", RIHA Journal, July (20I2); Theresa Papanikolas, Anarchism and the Advent of Paris Dada (Burlington, VT, 2010); Patricia Leighten, The Liberation of Painting: Modernism and Anarchism in Avant-Guerre Paris (Chicago, IL, 20I3).

78. In 1899, Lazare asked Grave for information about London's Jewish working-class areas ("Bricklane and Whitechapel"), the local revolutionary movement, as well as the International Working Men's Club, and also requested several issues of the local paper The Worker's Friend [sic]. Philippe Oriol (ed.), Bernard Lazare. Lettres à Jean Grave (Au Fourneau, I994), letter IX, pp. $24-25$.

79. In September I 893, he requested the address of an Australian companion, one address in Italy, and two further individual contacts, with a view to creating links with Romanian and Bulgarian comrades. Oriol, Lettres à Jean Grave, letter IV, p. I7.

80. Lazare offered Grave to reprint his material in his papers, and, in return, to publish Grave's own writings in his review Les Entretiens. Oriol, Lettres à Jean Grave, letter I, p. I 3.

8I. Jean Grave, Mémoires d'un anarchiste (Paris, 2009), p. 409.

82. Letter from Camille Pissarro to Grave, 4 May I900, Grave correspondence, IFHS.

83. Letter from Ludovic Pissarro to Grave, 21 March 1920, Grave correspondence, IFHS. 
One striking, lesser-known dimension was the reputational support for both Grave and the wider movement, especially during crises such as the "Trial of the Thirty" and the campaigns against Spanish atrocities. Grave developed occasional contacts and solid friendships with a progressive cross-political front. These links were mobilized on several occasions, and fulfilled an important role in giving the papers and the anarchist movement an aura which, at critical times, proved strategically or even vitally important. The "Trial of the Thirty", which marked the climax of

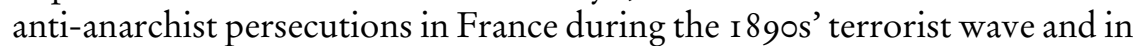
which Grave was indicted, illustrates the reputational impact of personal networks. Following his arrest, a group of prominent intellectuals and figures from a broad ideological spectrum spoke publicly in Grave's defence, with immediate impact; following interventions from the notorious anti-Semite Edouard Drumont, the Boulangist pamphleteer Henri de Rochefort and the prominent socialists Séverine and Clovis Hugues, his conditions of detention were relaxed. ${ }^{84}$ Lazare published a homage entitled "Jean Grave" on the day Grave appeared in court. High-profile figures testified in his defence, including Georges Clemenceau and even Drumont. ${ }^{85}$ His four witnesses were Elisée Reclus and three writers, Octave Mirbeau, Paul Adam, and Bernard Lazare. In his statement, Mirbeau acknowledged that he "only knew Grave through his writings, which [he] read with utmost interest" ${ }^{86}$ Grave, like many of those indicted, was acquitted in August I 894 and subsequently released following further public pressure.

This cross-political front, which mobilized for the defence of anarchism in the early I890s, was reactivated on a larger, transnational scale and in a more institutional way at the time of the Dreyfus Affair and the "Spanish Atrocities" campaigns from the late i 890 s to the I9Ios. ${ }^{87}$ Alongside anarchists, these causes drew support from socialists of different shades, freethinkers, masons, republicans, anti-clericals, and intellectuals. This intellectual solidarity was symptomatic of the political radicalization of literary figures in late nineteenth-century France, for which

84. Marc Stéphane, Pour Jean Grave (Paris, December i 894), n.p.

85. Patsouras, The Anarchism of Jean Grave, p. 5 I.

86. Extracts from Emile de Saint-Auban, L'Histoire sociale au Palais de Justice, plaidoyers philosophiques (Paris, I895), available at: http://kropot.free.fr/Graver.htm; last accessed 3 June 2016.

87. Letter from Grave to Lucien Descaves soliciting his help for a single-issue paper and general support for Spanish anarchists (alongside other prominent non-anarchist figures), Lucien Descaves Papers, IISH, “Jean Grave” file, letters dated 9 February I 897, I 8 January I 897, I 3 June I 897; Grave papers, IISH, Letters from Angiolillo and others to Grave, I897-1898; Joseph Presburg papers, Correspondence with Jean Grave, inv. no. 26, IISH; Daniel Laqua, "Freethinkers, Anarchists and Francisco Ferrer: The Making of a Transnational Solidarity Campaign", European Review of History, 21:4 (2014), pp. 467-484. 
anarchism provided a catalyst and which saw literary actors engaging in practical militancy. ${ }^{88}$ Until the Dreyfus Affair, such mobilizations could include far-right figures (such as Drumont, Adam, or Barrès) drawn to anarchism's individualism, libertarianism, and radical rejection of the state. ${ }^{89} \mathrm{In}$ the long term, these associations were vital in protesting against anti-anarchist repression, and in inscribing the movement and its actors (not least Grave) in a broad progressive tradition. Conversely, this solidarity with the anarchists and, for many writers, the engagement with anarchist ideas were important milestones in the emergence of the figure of the French intellectual $9^{\circ}$ - the very word intellectuel, revealingly, was used repeatedly during Grave's trial, several years before the Dreyfus Affair with which it is usually connected. ${ }^{9 \mathrm{I}}$

\section{THE PERIODICALS AS A NETWORKING TOOL}

Several conclusions emerge from the survey of Grave's networks and may be extrapolated to other contemporary anarchist movements. First, they show the effectiveness of print-mediated militancy and the diversity of functions performed by personal networks, as well as their importance in creating and sustaining political activism and a shared culture on a variety of scales. As summarized by James Yeoman, the press "played a decisive role in the cultural construction of anarchism as an identity, an ideology and a movement". ${ }^{2}$ Grave's newspapers and the associated Publications de la Révolte and Temps Nouveaux functioned as platforms for a wide repertoire of militant activities, and as exchange fora and meeting points for the communities which they structured at least partly. The essential organizing role of anarchist papers in a national context has been stressed by Jean Maitron and Alain Droguet, who identified three key functions for the anarchist press: spreading political views, arguing for revolutionary change and - a less usual role, more specific to anarchism - serving as an organization, a party. Maitron and Droguet counted Les Temps Nouveaux among a handful of pre-19I4 widely read and influential papers, which they identified as "a centre for the movement - providing coordination, or even direction". ${ }^{3}$

88. Justin Moisan, “Quand l'édition devient terroriste. Solidarité intellectuelle chez Jean Grave et Octave Mirbeau à la fin du XIXe siècle en France”, in Mémoires du livre / Studies in Book Culture, 3:I (20I I), para. I9.

89. Sonn, Anarchism \& Cultural Politics, pp. $3 \mathrm{I}-48$.

90. Justin Moisan, “Octave Mirbeau et la 'Terreur' anarchiste” (MA, University of Laval, 20I2), pp. 99-102.

91. Vincent Duclert, L'Affaire Dreyfus (Paris, 2009), p. 68; Christophe Charle, Naissance des “intellectuels”, I880-I900 (Paris, I990).

92. James Yeoman, "Print Culture and the Formation of the Anarchist Movement in Spain, 1890-1915” (PhD, University of Sheffield, 2016), p. 7.

93. Jean Maitron and Alain Droguet, "La presse anarchiste française de ses origines à nos jours", Le Mouvement social, 83 (1973), pp. 9-22, 9. 
First and foremost, the periodicals were a medium for theoretical elaboration and discussion, playing a pivotal role in the development and spread of anarchist communist ideology in the French-speaking world and globally. This was achieved through feature articles, long-running debates and discussions, and through brochures published alongside the papers, usually with stunning illustrations. As noted above, the papers were pivotal for the diffusion of Kropotkin's ideas and anarchist communism in general. René Bianco has noted that the Révolté team "had no qualms in stepping in to correct what [they] perceived as doctrinal deviations", while the paper's successors also functioned as "the 'doctrinaire' organ of communist-anarchists". ${ }^{94}$ This stance and the publications' somewhat dry style partly account for Grave's infamous nickname, "the Pope of the rue Mouffetard" (after the name of the Parisian street where the periodicals were produced), bestowed upon him by fellow anarchist and occasional collaborator Charles Malato. As stressed by Maitron, the newspapers were informative tools, publicizing news on labour and anarchist activism through "Mouvement Social" sections reporting on militant activities and developments in labour movements in localities both close and remote. Grave stated in his autobiography that he wanted to have a network of international correspondents, but often had to make do with lifting information from foreign papers. ${ }^{95}$ Thirdly, the seemingly irrelevant or paratextual sections "Correspondances et Communications" and "Petites Correspondances" provided essential grassroots links between individuals and groups at the local, regional, national, and international levels, thus structuring the anarchist world on a variety of scales. They contained very diverse information: publicity for militant events, coded correspondence notes, magazine subscriptions, and ads for the resale of propaganda material. These notes delineate a social history of anarchist politics, and show the periodicals' organizing role as platforms for information exchange, publicizing activist undertakings, and building unity.

Tapping into the strength of his networks, Grave also used his papers for campaigning purposes, most notably against political and clerical repression in Spain at the turn of the century. In this instance, Les Temps Nouveaux was involved in awareness-raising activism and network organizing. Such a global project required a linguistic strategy, or at least facilitation. Multilingual militants were instrumental in introducing the paper into and liaising with foreign groups, some of them probably acting as interpreters in the context of group readings. The papers' production relied on a few multilingual comrades who acted as translators. Esperanto, which anarchists had embraced as part of internationalist ideas, does not appear to have

94. Bianco, “Le Révolté”, n.p.

95. Grave, Le Mouvement Libertaire, p. I57. 
been used. As mentioned above, there is no evidence suggesting that Grave spoke any foreign language, although his second wife, Mabel Holland Thomas, was British..$^{96}$

Another point of note is the implementation of proactive networking strategies and network mobilization, based on a clear propaganda project. Network building was an important focus for Grave, to support his publications as well as specific causes. His constant efforts to seek and diffuse information about foreign movements and make contact with new groups and individuals were integral to the "project for the organization of propaganda which [he] intended to lead through the paper", ${ }^{97}$ as recounted in his autobiography: "The papers were read and had subscribers wherever there were active anarchist groupings in the most unexpected places. Governments in Latin and Central America sent us their own official papers in exchange for Les Temps Nouveaux [...]. I was once told that Malatesta, when he visited Tierra del Fuego, found an issue of Le Révolté in the first hut he entered." ${ }^{98}$ Grave evidently had a very clear conception of his publications' role in a global revolutionary movement, and pursued it actively. As he wrote to Gross: "In my view, publishing a paper must serve propaganda and 'hook' readers, and it should not be read only by a closed circle of readers who are already converts [...]. Without vanity, [...] I think that Les Temps Nouveaux holds a different place in the global anarchist movement." 99

Formal and informal links also enabled the circulation of money. Financial assistance travelled in both directions between Kropotkin and Grave, who never shied away from asking for financial help in his publications; auctions and fundraising events were organized, especially in times of difficulty, and all of Grave's connections and the periodicals' readers were called upon for financial support. A routine exchange with Jacques Gross provides an insight into such daily multidirectional financial transactions: "I will pass on the 50 francs to those prisoners I can [sic]. I will write to Brussels for Moineau and Tondeur. Also to the Monod and Courtois families, and those whose families I can find. As for the 50 francs for Italy, I will send them to Malatesta. He is the only who will know where to send them." roo

\section{CONCLUSION}

World War I brought this "heroic period" to a definite close. In August I9I4, Grave experienced a dramatic ideological reversal, following

96. See for instance the letter from Kropotkin dated 3 September 1894 , Grave correspondence, IFHS: "I could send you an excellent and easy book to learn English, if you like".

97. Letter to Paul Eltzbacher, I6 January 1922, Paul Eltzbacher Papers, IISH.

98. Grave, Le Mouvement Libertaire, p. I56.

99. Letter to Jacques Gross, 29 October I919, Jacques Gross Papers, inv. no. 47, IISH.

100. Letter from Grave to Jacques Gross, is January i 896; letter to Nettlau, 5 May igi 2, inv. no. 504, IISH, mentioning "Sir Isambard Owen, my brother in law". 
Kropotkin in supporting the war effort, after the latter famously castigated him for living "in a world of illusions", with his advocacy of peace and disarmament, and told him instead to "beat that army, reconquer Belgium [...] arm up", and urge comrades to do the same. ${ }^{\text {IOI }}$ Grave followed suit - a momentous yet surprisingly quick decision, which may be explained by his allegiance to Kropotkin and was part of the wide-ranging ideological repositioning of anarchists as a result of the war. ${ }^{102}$ Grave later explained his decision to Nettlau in a heated epistolary exchange. Fighting off accusations of patriotism, he focused on his pragmatic response and the gap between theory and practice: "No, no and no, I never reneged on any of my ideas [...]. The comrades and I did not follow any idea of patriotism, we considered only the regression which the victory of German militarism would have inflicted upon all of mankind, upon the idea of liberty [...]. The circumstances had changed since the time I wrote all these articles". ${ }^{\text {103 }}$

Grave went on to spend most of the war in Britain, near Bristol, the area from where his well-connected wife originated. ${ }^{104}$ The post-191 8 period was a time of generational change and personal and political loss for this generation. Reeling from the war, its ideological divisions, and the marginalization of the anarchist currents they were associated with, Grave and other French historic militants like Faure "barely survived". ${ }^{\circ 5}$ Grave was expelled from the Temps Nouveaux group in 1920 and, from then on, published only small irregular brochures. He was also crippled by financial difficulties, as attested by his correspondence with Ramus, where the sale of stamps as a precarious way of collecting funds became a central theme. ${ }^{\text {I06 }}$ However, his relational conception of activism remained unchanged in these far less propitious conditions, as evidenced by his attempts to resurrect networks in order to gather information and material for his pamphlets: "May I ask you to send me an article about the situation in Germany, and how liberal people view the occupation of the Ruhr? The papers here are poisoning the population and it would be good, with my limited means, to publicize the opposite positions." “o7 And he still pursued the same connected vision of anarchist militancy: "Our dream

IOI. Letter to Jean Grave, 2 September 1914, Grave correspondence, IFHS.

I02. On this topic, and Kropotkin's views in particular, see the recently edited volume by Kinna and Adams, Anarchism, I9I4-I8.

103. Letter to Max Nettlau, Io August 1922, Max Nettlau Papers, inv. no. 505, IISH.

104. Letter to Jacques Gross dated October I9I s, Jacques Gross Papers, IISH.

I05. Jean Maitron and Colette Chambelland, "La correspondance de Jean Grave. Inventaire et études", L'Actualité de l'histoire, 24 (1958), pp. 39-46.

106. Pierre Ramus Papers, inv. no. 57, IISH (correspondence with Jean Grave), letters dated 27 November 1921, is June 1924.

107. Letter from Grave to Paul Eltzbacher, 24 February 1922, Paul Eltzbacher Papers, IISH. 
would be to help the reorganization of anarchists by making them understand the need to group and keep in contact with one another." ${ }^{\circ} 8$

This poignant epilogue and Grave's siding with the interventionist anarchists during the war have no doubt contributed to obscuring his long militant career, perhaps compounding his taciturn character and the relative discretion inherent in relying on print as the main medium for his activism. There is indeed much to discover, and rediscover, about Grave and his militancy: his print-based activism highlights his remarkable achievements as an organizer of propaganda, as evidenced, inter alia, by the longevity, scope, and influence of Temps Nouveaux. Ironically, while Grave himself has been partly forgotten or simply overlooked, his efforts to organize anarchism transnationally and his ceaseless promotion of anarchist cultural politics were central to the movement's legacy and long-term countercultural influence. This investigation has broader implications, highlighting the transnational elaboration and diffusion of French anarchism, and its inclusion in a progressive front, which was important for the movement's publicity, resilience, and legacy. Examining the proactive strategies underpinning networked activism paves the way for a material history of militancy analysing the practical and financial modalities of the dissemination of propaganda. More research is needed to fully map out Grave's connections over time and, more specifically, to assess the ideological assumptions often implicit in networked organization, such as the possible dominance of charismatic leaders (including Grave himself), the lack of clear mechanisms of accountability, Western-centric diffusionist assumptions, and the relative lack of scholarly attention paid to the importance of the local due to the current focus on movement and transfers. ${ }^{1 \circ 9}$ Grave's example will also provide an excellent testing ground for these research themes.

\section{TRANSLATED ABSTRACTS \\ FRENCH - GERMAN - SPANISH}

Constance Bantman. Jean Grave et l'anarchisme français: une approche relationnelle (années I870-1914).

Cet article propose une approche biographique dans l'étude de l'activisme anarchiste de Jean Grave. Journaliste, rédacteur, théoricien, romancier, éducateur et militant,

I08. "Publications de la Révolte et des Temps Nouveaux", I920, n. I, Publications du "Groupe de propagande par l'écrit".

I09. Sian Byrne and Lucien van der Walt, "Worlds of Western Anarchism and Syndicalism: Class Struggle, Transnationalism, Violence and Anti-Imperialism, I870s-1940s", Canadian Journal of History/Annales canadiennes d'histoire, 50:I (2015), pp. 98-123, I09-1 10; Maxwell and Craib, No Gods, No Masters, No Peripheries, p. 2; Donna Gabaccia, "Afterword”, Zapruder World: An International Journal for the History of Social Conflict, I (2015), available at: http://www. zapruderworld.org/volume-I-afterword; last accessed 30 May 2016. 
Jean Grave fut l'une des plus influentes figures du mouvement anarchiste français et transnational entre la fin des années i 870 et la Première Guerre mondiale. L'article, adoptant une approche relationnelle des relations formelles et informelles de Grave, se concentre sur le rôle de la chose imprimée dans l'activisme de Grave par le biais des trois journaux qu'il publia entre I883 et I9I4, et met l'accent sur ses relations transnationales et liens avec des cercles progressistes en France. Vu la place centrale de Grave et de ses publications dans le mouvement anarchiste français, cette approche biographique et relationnelle offre une base pour reconsidérer le fonctionnement et les grandes orientations stratégiques du communisme anarchiste français durant sa "période héroïque" (I870-19I4), en soulignant ses ramifications et ses liens au-delà du mouvement anarchiste.

Traduction: Christine Plard

Constance Bantman. Jean Grave und der französische Anarchismus. Eine relationale Herangehensweise (I870er Jabre bis I9I4).

Der Beitrag schlägt eine biografische Herangehensweise an die Untersuchung des anarchistischen Aktivismus vor und wendet eine solche auf den französischen Journalisten, Herausgeber, Theoretiker, Romanautor, Pädagogen und Organisator politischer Kampagnen Jean Grave an. Bei Grave handelt es sich um eine der einflussreichsten Gestalten der französischen und internationalen anarchistischen Bewegung im Zeitraum zwischen den i 870er Jahren und dem Ersten Weltkrieg. Der Beitrag folgt einem relationalen Ansatz, bei dem es darum geht, Graves formelle und informelle Verbindungen zu anderen Personen nachzuzeichnen, und konzentriert sich auf die Rolle, die das gedruckte Wort in Graves Aktivismus gespielt hat, insbesondere in Form der drei Zeitungen, die er zwischen I 883 und I9I4 herausgegeben hat. Dabei werden Graves länderübergreifende Kontakte und seine Verbindungen zu fortschrittlich eingestellten Kreisen in Frankreich hervorgehoben. Angesichts der zentralen Bedeutung, die sowohl Grave als auch seinen Veröffentlichungen für die französische anarchistische Bewegung zukommt, bietet die biografische und relationale Herangehensweise eine Grundlage für die Neubewertung der Wirkungsweise und der wesentlichen strategischen Ausrichtungen des französischen anarchistischen Kommunismus während seiner "heroischen Phase" (von den I $870 e r$ Jahren bis I9I4), und zwar durch die Betonung transnationaler Verzweigungen und über die anarchistische Bewegung hinausreichender Verbindungen.

Übersetzung: Max Henninger

Constance Bantman. Jean Grave y el anarquismo francés: un enfoque relacional (I870-I9I4).

En este artículo se propone un enfoque biográfico al estudio del activismo anarquista aplicado al periodista francés, editor, teórico, novelista, educador y movilizador Jean Grave, una de las figuras que ha tenido mayor influencia en el movimiento anarquista tanto francés como internacional entre finales de la década de i 870 y la Primera Guerra Mundial. A partir de una aproximación relacional se perfilan las conexiones 
tanto formales como informales de Grave y prest atención al papel de lo impreso en su activismo a partir del estudio de tres de los periódicos que el editó entre i 883 y I9I4. Se destacan en el texto, además, las conexiones transnacionales y los vínculos con los círculos progresistas en Francia. Dado el lugar central que ocupan tanto la figura de Grave como sus publicaciones en el anarquismo francés, este enfoque biográfico y relacional que proponemos proporciona una base sobre la que replantear el funcionamiento y las orientaciones estratégicas fundamentales del anarcocomunismo francés a lo largo de su "periodo heroico" (entre la década de 1870 y I9I4), prestando especial atención a las ramificaciones transnacionales y a los vínculos existentes tras el movimiento anarquista.

Traducción: Vicent Sanz Rozalén 